\title{
Immunohistological determination of proliferative activity in seminomas
}

\author{
W DÜE, * K-P DIECKMANN, $†$ V LOY* \\ From the *Institute of Pathology and the †Department of Urology, Klinikum Steglitz, Free University of Berlin, \\ West Germany
}

SUMMARY The proliferative activity and growth pattern of 20 seminomas were determined immunohistologically with the monoclonal antibody Ki-67. A growth fraction of tumour cells between 50 and $80 \%$ was found in seminomas with an almost even distribution of proliferating cells in all sections, regardless of tumour size. There was a slight tendency towards a greater growth fraction in tumours at an advanced histopathological stage. No positive correlation could be found between growth fraction and tumour size or lymphocytic infiltration.

The results confirm the well known sensitivity of seminomas to radiation and chemotherapy and show that the determination of proliferative activity should be included in the histopathological routine diagnosis of malignant tumours with regard to systemic treatment and prognosis.

Pure seminomas comprise about $40 \%$ of malignant testicular germ cell neoplasms. ${ }^{1-3}$ The incidence peaks in the third to fifth decade and has continued to rise over the past 20 years. ${ }^{34}$ Histopathological methods should therefore be used to integrate the assessment of relevant biological variables into the routine diagnosis of seminomas. This study investigated the association between the proliferative behaviour of seminomas with other histomorphological as well as clinical variables. The use of immunohistochemistry in conjunction with the monoclonal antibody $\mathrm{Ki}-67$ facilitates determination of the proportion of proliferating tumour cells, which is important in view of the implications for the prognosis with and without treatment and to explain cases of unexpected brevity of survival.

\section{Material and methods}

Twenty seminomas surgically removed between 1984 and 1987 were subjected to immunohistological determination of the growth fraction of tumour cells. Histologically the tumours were typical seminomasthat is, anaplastic or spermatocytic seminomas were not included. No other tumour component was present. The age of the patients ranged between 26 and 54 years; tumour size ranged from 1 to $12 \mathrm{~cm}$ in diameter and from 1 to $972 \mathrm{~cm}^{3}$ in volume (table 1).

For immunohistological analysis, several unfixed samples from each tumour were stored at $-80^{\circ} \mathrm{C}$

Accepted for publication 3 September 1987 immediately after orchidectomy or biopsy. The highly sensitive alkaline phosphatase-antialkaline phosphatase (APAAP) staining procedure, ${ }^{5}$ modified by Stein $e a^{6}{ }^{6}$ was applied to cryostat sections. In cases in which endogenous alkaline phosphatase could not be blocked sufficiently the immunoperoxidase technique was applied to prevent the nuclear reaction product from being covered by cytoplasmatic phosphatase.

The monoclonal antibody $\mathrm{Ki}-67^{7}$ detects a proliferation-associated antigen in the nucleus which is expressed in all states of the cell cycle except $G_{0}$. With the APAAP technique, the reaction product is red in colour and can easily be detected regardless of the tissue being counterstained with haematoxylin.

The fraction of proliferating cells was determined by counting the tumour cells stained by $\mathrm{Ki}-67$ in five high power fields at a magnification of 420 and the unreactive tumour cells in the same fields for each case (about 700 to 900 tumour cells). Lymphocytic infiltration was likewise determined in formaldehyde fixed and paraffin embedded tissue by counting lymphocytes in five representative high power fields $(\times 420)$ for each tumour and calculating the average number of lymphocytes.

All patients were staged histopathologically according to the International Union against Cancer classification system. ${ }^{8}$

\section{Results}

Histopathological staging confirmed four cases ai stage pT1, two at stage pT2, and 14 cases at stage pT3 
thus $70 \%$ of our cases showed infiltration of rete testis. Fourteen cases were classified as $\mathrm{N}_{0}$, three as $\mathrm{N}_{2}$, and three as $\mathrm{N}_{3}$; one of the patients with lymph node stage $\mathrm{N}_{3}$ also had metastases in the liver, defined as stage M1 (table 1).

Case 8 had evidence of focal selections of epitheloid cells as well as a considerable number of Langhans' giant cells. Varying amounts of lymphocytes ranging from about 40 to 500 per high power field were seen, with formation of lymph follicles in cases 16 and 18 . The lymphocytic infiltration was mostly concentrated in the supporting stroma and sometimes scattered in clumps throughout the tumours. Extensive necrosis was found in cases $3,5,6,10$, and 17 and circumscribed necrosis in well restricted areas in cases 13 and 19. In these, lymphocytic infiltration was not determined in areas adjacent to tumour necrosis. Tumour diameter and volume varied considerably (table 1 ).

For immunohistological determination of proliferating tumour cells, the APAAP technique was successfully applied in 17 of our 20 cases. The remaining three cases were examined by the immunoperoxidase technique.

Use of $\mathrm{Ki}-67$ showed a fraction of proliferating tumour cells ranging between 50 and $80 \%$ (table 1 ). In most cases, the nucleoli in particular stained strongly (figure), in an intranuclear pattern of granules and clots of irregular density. Despite varying intensity the reaction product was clearly visible. Thus reactive and non-reactive tumour cells-that is, proliferating tumour cells and those in the $G_{0}$ state-could easily be distinguished. The distribution of proliferating cells

Table 1 Summary of pathological, immunohistological and clinical data

\begin{tabular}{|c|c|c|c|c|c|c|c|c|c|}
\hline $\begin{array}{l}\text { Case } \\
\text { No }\end{array}$ & Age & $\begin{array}{l}\text { Percentage } \\
\text { of Ki-67 } \\
\text { positive } \\
\text { cells }\end{array}$ & Staging & $\begin{array}{l}\text { Volume } \\
\left(\mathrm{cm}^{3}\right)\end{array}$ & $\begin{array}{l}\text { Lymph* } \\
\text { cells }\end{array}$ & Necrosis & Treatment & $\begin{array}{l}\text { Outcome } \\
\text { (survival } \\
\text { in months) }\end{array}$ & \\
\hline 1 & 44 & 50 & pT3 N0 M0 & 10 & 170 & None & Semicastration, & No evidence of disease & 7 \\
\hline 2 & 46 & 50 & pT3 N2 M0 & $128 \ddagger$ & 260 & None & $\begin{array}{l}\text { Semicastration, } \\
\text { radiotherapy }\end{array}$ & No evidence of disease & 19 \\
\hline 3 & 43 & 50 & pT3 N3 M0 & 630 & 81 & Extensive & $\begin{array}{l}\text { Semicastration, } \\
\text { chemotherapy }\end{array}$ & No evidence of disease & 14 \\
\hline $\begin{array}{l}4 \\
5\end{array}$ & $\begin{array}{l}29 \\
36\end{array}$ & $\begin{array}{l}50 \\
55\end{array}$ & $\begin{array}{l}\text { pT1 N2 M0 } \\
\text { pT2 N0 M0 }\end{array}$ & $\begin{array}{l}37 \\
98\end{array}$ & $\begin{array}{r}97 \\
314\end{array}$ & $\begin{array}{l}\text { None } \\
\text { Extensive }\end{array}$ & $\begin{array}{l}\text { Semicastration } \\
\text { Semicastration, } \\
\text { radiotherapy }\end{array}$ & $\begin{array}{l}\text { Died of other causes } \\
\text { No evidence of disease }\end{array}$ & $\begin{array}{r}11 \\
7\end{array}$ \\
\hline 6 & 29 & 55 & pT3 N0 M0 & 45 & 399 & Extensive & $\begin{array}{l}\text { Semicastration, } \\
\text { radiotherapy }\end{array}$ & No evidence of disease & 21 \\
\hline 7 & 36 & 55 & pT1 N0 M0 & 19 & 36 & None & $\begin{array}{l}\text { Semicastration, } \\
\text { radiotherapy }\end{array}$ & No evidence of disease & 12 \\
\hline 8 & 26 & 60 & pT1 N0 M0 & 4 & 500 & None & $\begin{array}{l}\text { Semicastration, } \\
\text { radiotherapy }\end{array}$ & No evidence of disease & 10 \\
\hline 9 & 49 & 60 & pT3 N0 M0 & 15 & $135+t$ & None & $\begin{array}{l}\text { Semicastration, } \\
\text { radiotherapy }\end{array}$ & No evidence of disease & 7 \\
\hline 10 & 54 & 60 & pT3 N2 M0 & 9 & 300 & Extensive & $\begin{array}{l}\text { Semicastration, } \\
\text { radiotherapy }\end{array}$ & No evidence of disease & 20 \\
\hline 11 & 30 & 60 & pT3 No M0 & 6 & 290 & None & $\begin{array}{l}\text { Semicastration, } \\
\text { radiotherapy }\end{array}$ & No evidence of disease & 26 \\
\hline 12 & 30 & 60 & pT3 No M0 & 1 & 460 & None & $\begin{array}{l}\text { Semicastration, } \\
\text { radiotherapy }\end{array}$ & No evidence of disease & 20 \\
\hline 13 & 44 & 65 & pT1 N3 M0 & 972 & 90 & Circumscribed & $\begin{array}{l}\text { Semicastration, } \\
\text { chemotherapy, } \\
\text { radiotherapy }\end{array}$ & No evidence of disease & 19 \\
\hline 14 & 45 & 70 & pT2 N0 M0 & 154 & 83 & None & $\begin{array}{l}\text { Semicastration, } \\
\text { radiotherapy }\end{array}$ & No evidence of disease & 12 \\
\hline 15 & 41 & 70 & pT3 N0 M0 & 144 & 350 & None & $\begin{array}{l}\text { Semicastration, } \\
\text { radiotherapy }\end{array}$ & No evidence of disease & 20 \\
\hline 16 & 29 & 70 & pT3 N3 M1 & 1 & 250 & None & $\begin{array}{l}\text { Semicastration, } \\
\text { radiotherapy, } \\
\text { chemotherapy }\end{array}$ & Died of disease & 28 \\
\hline 17 & 47 & 70 & pT3 N0 M0 & 429 & 115 & Extensive & $\begin{array}{l}\text { Semicastration, } \\
\text { radiotherapy }\end{array}$ & No evidence of disease & 35 \\
\hline 18 & 38 & 75 & pT3 N0 M0 & 180 & 310 & None & $\begin{array}{l}\text { Semicastration, } \\
\text { radiotherapy }\end{array}$ & No evidence of disease & 4 \\
\hline 19 & 32 & 75 & pT3 No M0 & 7 & 240 & Circumscribed & $\begin{array}{l}\text { Semicastration, } \\
\text { radiotherapy }\end{array}$ & No evidence of disease & 23 \\
\hline 20 & 31 & 80 & pT3 N0 M0 & 180 & 180 & None & $\begin{array}{l}\text { Semicastration, } \\
\text { retroperitoneal } \\
\text { lymphadenectomy }\end{array}$ & No evidence of disease & 4 \\
\hline
\end{tabular}

*Average number of lymphocytes per high power field.

ttumour metastases in the liver:

fonly one diameter reported, the others set to $50 \%$ of the largest;

†+tumour with granulomatous reaction. 


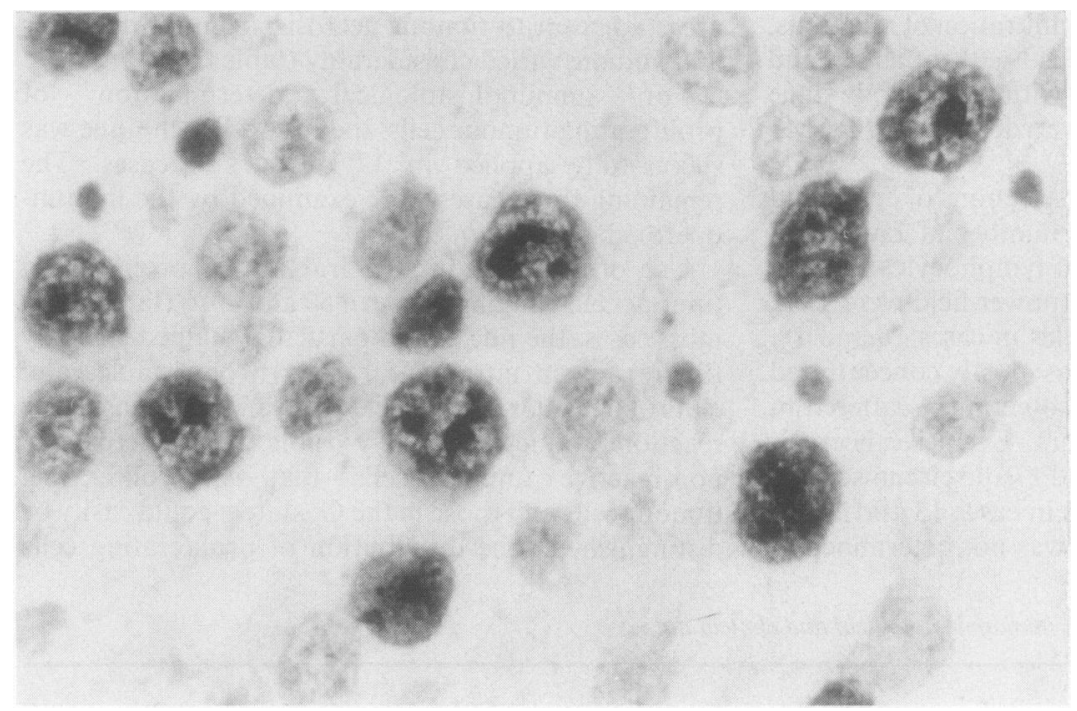

Figure Immunohistological staining of proliferating seminoma cells by monoclonal antibody Ki-67. Intranuclear reaction product is clearly visible in about $50 \%$ of tumour cells.

Table 2 Tumour stage $v$ average proportion of proliferating tumour cells

\begin{tabular}{llll}
\hline Stage $(p T)$ & \multicolumn{3}{c}{ Stage $(N)$} \\
\hline pT1 & $57 \cdot 5 \%$ & N0 & $63.9 \%$ \\
pT2 & $62 \cdot 5 \%$ & N1-3 & $57 \cdot 5 \%$ \\
pT3 & $63 \cdot 2 \%$ & & \\
\hline
\end{tabular}

was almost uniform throughout our samples, the edge length being about $0.9 \mathrm{~cm}$; cryostat sections were $7 \mu \mathrm{m}$ thick.

Table 2 shows the correlation between the fraction of proliferating tumour cells detected by $\mathrm{Ki}-67$ and the pathological stage. There was a slight tendency towards a greater growth fraction the more advanced the pT stage, the proportion of proliferative cells ranging from about 57 to $63 \%$. Cases with lymph node stage N0 tended to have a smaller growth fraction in the primary tumours compared with stage $\mathbf{N}_{1-3}$ seminomas (table 2).

There was no positive correlation between growth fraction and density of lymphocytic infiltrate. Almost all percentiles of the growth fraction comprised specimens with both dense and scanty infiltration. The one case with a granulomatous reaction fell within the intermediate range of proliferative activity.

It is obvious that there was no clearcut association between growth fraction and volume of tumour mass, but most of those tumours with a larger volume were in the upper range of proliferative activity.

The time from initial surgery up to the date of this study ranged between four and 35 months. Thus comparability of the follow up data is somewhat limited. Case 16, with seminoma metastases in the liver, died of the disease 27 months after diagnosis, and case 4, 11 months after diagnosis of other causes. All other patients were still alive without recurrent disease at the time of writing.

\section{Discussion}

This study shows that the overall growth fraction of seminomas ranges from 50 to $80 \%$ with an average of over $60 \%$. This finding agrees with the proliferative activity in seminomas detected by ${ }^{3} \mathrm{H}$-thymidine labelling in vivo ${ }^{910}$ and in vitro. ${ }^{11} \mathrm{~A}$ homogeneous pattern of proliferating cells was found in all of our specimens, which agrees with the findings of Silvestrini et al. ${ }^{10}$

There was no positive correlation between proliferative activity and tumour size at the time of diagnosis, ${ }^{412}$ because rapidly growing tumours are detected and removed at an earlier stage of growth. ${ }^{13}$ The assumption that proliferative activity and invasive behaviour may be divergent attributes of tumour cells ${ }^{14}$ is corroborated by the negative correlation shown between lymph node stage and growth activity in seminomas. This tendency, however, was barely perceptible and needs to be confirmed in a greater number of cases. Silvestrini et al found an opposite tendency, but no significant association between tumour growth and lymph node stage by $\mathrm{H}^{3}$ thymidine labelling."

No association was observed between grade of 
atypia and growth fraction. Hence proliferative activity determined by immunohistological examination is not a reliable criterion for defining anaplastic seminoma, ${ }^{91516}$ an aspect already noted by Hochstetter ${ }^{17}$ in relation to the mitotic index.

In accordance with Rabes $e t$ al this study could find no correlation between lymphocytic infiltration and proliferative activity. ${ }^{9}$ Some studies ${ }^{41215}$ have found an association between lymphocytic infiltration and prognosis, but infiltration has not been positively correlated with tumour growth.

Only one patient in our series died of a seminoma. Thus at present no convincing conclusions can be drawn from this study in respect to the prognostic importance of rate of growth. The association with prognosis was not examined in the studies quoted above. ${ }^{10} 11$ Determination of mitotic index is the only method for assessing the proliferative activity that has been correlated with the prognosis of seminomas, but the results have been inconsistent.' Survival alone cannot be regarded as a criterion for the determination of prognosis as the survival of treated patients is more than $90 \%$. Thus the term "prognosis" has to be redefined for seminomas. ${ }^{13}$

Proliferating cells are much more sensitive to radiotherapy and chemotherapy than non-proliferating cells. ${ }^{18-20}$ Hence the high proliferative activity not only confirms the data yielded by ${ }^{3} \mathrm{H}$-thymidine labelling but also explains the well documented sensitivity of seminomas to radiotherapy ${ }^{182 t-24}$ and chemotherapy. ${ }^{24-27}$

Determining the growth fraction may, in selected cases, influence therapeutic decisions-for example, in favour of forced systemic treatment in cases with extremely high proliferation, and surgery in those with low proliferative activity. The use of the monoclonal antibody $\mathrm{Ki}-67$ is - as has recently been stated by Gatter et $a l^{28}$ - a reliable and easy method for routine histopathological diagnosis and is thus also a useful part of the diagnostic panel in seminomas.

We thank Mrs H Steeger, K Stamatoukou, M Thiel, I Winter and Mr D Born for their excellent technical assistance.

\section{References}

1 Mostof FK. Pathology of germ cell tumors of testis. Cancer 1980;45:1735-54.

2 Pugh RCB. Pathology of the testis. Oxford: Blackwell Scientific Publications, 1976.

3 Waterhouse JAH. Epidemiology of testicular tumors. J R Soc Med 1985;78(Suppl 6):3-7.

4 Thackray AC, Crane WAJ. Seminoma. In: Pugh RCB, ed.
Pathology of the testis. Oxford, Blackwell Scientific Publications 1976:164-97.

5 Cordell JL, Falini B, Erber WN, et al. Immunoenzymatic labelling of monoclonal antibodies using immune complexes of alkaline phosphatase and monoclonal antialkaline phosphatase (APAAP) complexes. J Histochem Cytochem 1984;32:219-29.

6 Stein H, Gatter K, Asbahr H, Mason DY. Use of freeze-dried paraffin-embedded sections for immunohistologic staining with monoclonal antibodies. Lab Invest 1985;52:676-83.

7 Gerdes J, Lemke H, Baisch H, Wacker H-H, Schwab U, Stein H. Cell cycle analysis of a cell proliferation-associated human nuclear antigen defined by the monoclonal antibody $\mathrm{Ki}-67$. J Immunol 1984;133:1710-15.

8 International Union against Cancer. Klassifikation der Malignen Tumoren. 3rd ed. Berlin: Springer Verlag; 1979:118-21.

9 Rabbes HM, Schmmeller N, Hartmann A, Rattenhuber U, Carl P, Staehler G. Analysis of proliferative compartments in human tumors. II. Seminoma. Cancer 1985;55:1758-69.

10 Rabes HM. Proliferation of human testicular tumours. Int $J$ Androl 1987;10:127-37.

11 Silvestrini R, Costa A, Pilotti S, Pizzocaro G. Cell kinetics in human germ cell tumors of the testis. In: Pavone-Macaluso N, Smith PH, Bagshar MA, eds. Testicular cancer and other tumors of the genitourinary tract. New York: Plenum Press 1985:55-62.

12 Dixon FJ, Moore RA. Testicular tumors. Cancer 1953;6:427-54.

13 Dieckmann K-P, Becker T, Bauer HW. Testicular tumors: Presentation and role of diagnostic delay. Urol Int 1987;42:241-7.

14 Poste G, Fidler IJ. The pathogenesis of cancer metastasis. Nature 1980;283:139-46.

15 Mostofi FK. Testicular tumors. Cancer 1973;32:1186-201.

16 Mostofi FK, Price EB. Seminoma. In: Mostofi FK, Price EB, eds. Tumors of the male genital system. Atlas of tumor pathology. Second Series, Fascula 8. Washington, DC: AFIP, 1973:21-39.

17 Hochstetter von AR. Mitotic count in seminomas-an unreliable criterion for distinguishing between classical and anaplastic types. Virchows Arch (Pathol Anat) A 1981;390:63-9.

18 Valeriote F, van Putten L. Proliferation-dependent cytotixicity of anticancer agents: a review. Cancer Res 1975;35:2619-30.

19 Thomas GM. Controversies in the management of testicular seminoma. Cancer 1985;55:2296-302.

20 Breur K. Growth rate and radiosensitivity of human tumours-II. Radiosensitivity of human tumours. Eur J Cancer 1966;2: 173-88.

21 Einhorn LH, Williams SD. Chemotherapy of disseminated testicular cancer. Cancer 1980;46:1339-44.

22 Maier JG, Mittemeyer B. Carcinoma of the testis. Cancer 1977;39:981-6.

23 Caldwell WL, Kademian MT, Frias Z, Davis TE. The management of testicular seminomas, 1979. Cancer 1980;45:1768-74.

24 Schultz HP, von der Maase H, Rorth M, Pedersen M, Nielsen MS, Walbom-Jorgensen S. Testicular seminoma in Denmark 1976-1980. Acta Radiol Oncol 1984;23:263-70.

25 Peckham MJ, Horwich A, Hendry WF. Advanced seminoma: treatment with cis-platinum-based combination chemotherapy of carboplatin (JM8). Br J Cancer 1985;52:7-13.

26 Pizzocaro G, Salvioni R, Piva L, Zanoni F, Milani A, Faustini M. Cisplatin combination chemotherapy in advanced seminoma. Cancer 1986;58:1625-9.

27 Walther PJ, Paulson DF. Testicular seminoma revisited: time for a multimodal therapeutic approach. World J Urol 1984;2:68-72.

28 Gatter KC, Dunnill MS, Gerdes J, Stein H, Mason DY. New approach to assessing lung tumours in man. J Clin Pathol 1986;39:590-3.

Request for reprints to: Dr W Düe, Institut für Pathologie, Klinikum Steplitz der Freien Universität Berlin, Hindenburgdamm 30, D-1000 Berlin 45, West Germany. 